\title{
SENI DENDANG BENGKULU SELATAN
}

\section{DENDANG ARTS OF SOUTH BENGKULU}

\author{
Hasanadi \\ Balai Pelestarian Nilai Budaya Sumatera Barat \\ Jl. Raya Belimbing No. 16 A, Kuranji Kota Padang \\ E-mail: hasanassyahda@yahoo.co.id \\ Naskah diterima 9 Oktober 2018, diterima setelah perbaikan 26 November 2018, \\ disetujui untuk dicetak 28 November 2018
}

\begin{abstract}
Abstrak
Tulisan ini mengetengahkan pembahasan tentang sastra lisan Seni Dendang masyarakat Kabupaten Bengkulu Selatan Provinsi Bengkulu. Tulisan ini diramu ulang berdasarkan laporan penelitian yang bersifat kualitatif. Data penelitian dikumpulkan melalui studi kepustakaan, wawancara dan observasi lapangan serta dianalisis dengan menggunakan pendekatan analisis konten (kontent analiysis. Hasil analisis menunjukkan bahwa aspek sejarah dan sosial budaya Seni Dendang serta beberapa aspek pertunjukan Seni Dendang, seperti alat pertunjukan, waktu dan suasana pertunjukan, interaksi antara penampil dengan khalayak, teks, dan tari, merefleksikan nilai budaya masyarakat Bengkulu Selatan. Sebagai bagian dari kearifan lokal masyarakat Bengkulu Selatan, beberapa nilai budaya yang berhasil dijelaskan adalah, nilai seni, nilai pendidikan, nilai pengorbanan, serta nilai agama dan kepercayaan.
\end{abstract}

Kata kunci : nilai budaya, seni dendang, bengkulu selatan.

\begin{abstract}
Beyond this writing, including the oral literature of Dendang Art, the people of South Bengkulu Regency, Bengkulu Province. This paper is reconciled based on qualitative research reports. Research data was collected through literature study, interviews and in-depth interviews and analyzed using content analysis (content analysis. Results of analysis of aspects and sociocultural aspects of Dendang Art and several aspects, interactions, and interactions. Between viewers with audiences, texts, and dance, reflected values cultural values of the people of South Bengkulu. Part of the local wisdom of the people of South Bengkulu, several successful cultural values are, the basis, the value of education, the value of sacrifice, and the values of religion and belief.
\end{abstract}

Keywords: cultural value, dendang arts, south bengkulu. 


\section{PENDAHULUAN}

Seni Dendang Bengkulu Selatan terklasifikasi ke dalam sastra lisan yang lahir, tumbuh, dan berkembang terutama dalam konteks masyarakat tradisional. Sebagaimana ditulis Atmazaki (2005: 139 - 139), dari segi bentuk sastra lisan memiliki bentuk yang beragam, di antaranya berbentuk prosa naratif, berbentuk puisi (nyanyian rakyat) dan berbentuk prosa liris. Dari segi penciptaan, meskipun sastra lisan dianggap anonim, besar kemungkinan bahwa menghilangnya pencipta disebabkan karena sastra lisan merupakan pancarian kreasi masyarakat lama dan dianggap sebagai milik bersama. Dari segi pewarisan, sastra lisan biasanya diwariskan kepada orang-orang tertentu serta tidak semua orang boleh mewarisi sastra lisan, terutama yang berhubungan dengan kepercayaan atau mistik. Dari segi status sosial orang yang menyampaikan, ada penyampai yang berstatus sosial tinggi seperti pemangku adat, namun ada pula yang berstatus sosial rendah. Dari segi fungsi, sastra lisan memiliki banyak fungsi, di antaranya berfungsi untuk mengukuhkan solidaritas dan menyegarkan pikiran dan perasaan masyarakat.

Menurut Yarman HS, salah seorang seniman Seni Dendang Bengkulu Selatan (wawancara tanggal 13 Maret 2011), Seni Dendang atau biasa disebut dengan bedendang (berdendang), dalam pertunjukannya ada dua macam, yaitu bedendang nunggu nasi masak dan bedendang mutus tari. Pertunjukan Seni Dendang biasanya dilakukan untuk memeriahkan prosesi perkawinan yang diadakan oleh warga. Pada konteks itu, penampilan para seniman Seni Dendang dilakukan untuk memenuhi undangan warga yang mengadakan hajatan serta berfungsi sebagai hiburan atau pelipur lara. Kenyataan ini sesuai dengan penjelasan Wiliam R. Bascom tentang ciri sastra lisan yang kemudian membedakannya dengan kebudayaan lain, yaitu sebagai sistem proyeksi, yakni sebagai alat pencerminan angan-angan suatu kolektif, sebagai alat pengesahan pranata-pranata dan lembaga-lembaga kebudayaan, sebagai alat pendidikan anak, sebagai alat pemaksa dan pengawas agar norma-norma masyarakat selalu dipatuhi anggota kolektifnya, dan sebagai hiburan (Danandjaja, 1991 : 19).

Penampil Seni Dendang memakai pakaian garus berlengan panjang, peci (kopiah) hitam, kain sarung dan tidak boleh pakai celana. Biasanya kesenian ini dipertunjukan pada malam hari pesta perkawinan, yang dimulai sekitar pukul 21.00 wib serta berakhir sekitar pukul 24.00 wib. Pada setiap pertunjukan tersebutlah para seniman Seni Dendang berdendang diiringi oleh berbagai jenis tarian. Biasanya, ketika seorang penampil berdendang maka beberapa penampil lain akan menari diiringi alunan musik rebana, biola, dan serunai. Bersifat tradisional serta dengan peralatan seadanya para seniman Seni Dendang tetap bertahan meskipun perhatian Pemerintah Daerah Kabupaten Bengkulu Selatan dirasakan masih kurang. Sebagaimana diakui Khadam, seniman Seni Dendang Bengkulu Selatan (wawancara tanggal 13 Maret 2013), menjadi seniman tradisional yang bertugas melestarikan Seni Dendang belum menjadi pilihan yang proporsional, terutama dikaitkan dengan minimnya perhatian pemerintah serta kecilnya imbalan yang diperoleh ketika tampil menghibur masyarakat.

Struktur pertunjukan beserta nilai budaya Seni Dendang masyarakat Begkulu Selatan penting untuk dicermati. Pertama, terkait proses kreatif para seniman tradisional Seni Dendang yang merefleksikan adanya kepekaan dari sebagian kecil anggota masyarakat terhadap perlunya pelestarian seni tradisi. Kedua, berkenaan dengan nilai budaya Seni Dendang sebagai refleksi kearifan lokal (local wisdom) masyarakat Bengkulu Selatan yang dapat ditemukenali pada setiap 
pertunjukan yang digelar. Pada dua kepentingan itu, struktur pertunjukan dan nilai budaya seni tradisi, tulisan ini menjadi relevan terutama untuk tersedianya hasil kajian terkait Seni Dendang, sehingga usaha pelestarian serta pewarisan nilai budaya kepada masyarakat terus berlanjut. Melalui tulisan ini kiranya terjawab pertanyaan penting, bagaimana struktur pertunjukan dan nilai budaya Seni Dendang masyarakat Bengkulu Selatan?

\section{METODE PENELITIAN}

Produk sastra mempunyai otonomi yang hanya patuh pada dirinya sendiri (Teeuw, 1979: 11). Produk sastra merupakan hasil kerja seni kreatif yang memiliki keseluruhan yang bulat, yang berdiri sendiri sehingga menghendaki penafsiran dari perspektif sastra itu sendiri. Walaupun demikian, setiap cipta sastra semisal sastra lisan atau kesenian tradisional, khususnya yang berkembang dalam sistem sosial budaya masyarakat tradisional, tidak berfungsi dalam situasi kosong. Produk sastra merupakan aktualisasi atau realisasi tertentu dari sistem sosial dan budaya tempat di mana sastra tersebut hidup dan diwariskan (Atmazaki, 2005: 30). Senada dengan itu, Kayam (1981 : 38-39) menjelaskan bahwa kesenian tidak pernah berdiri lepas dari masyarakat. Sebagai bagian penting dari kebudayaan kesenian adalah ungkapan kreatifitas dari kebudayaan itu sendiri. Masyarakat yang menjaga kebudayaan dan kesenian yang mencipta, mengembangkan untuk kemudian menciptakan kebudayaan baru lagi.

Sebagaimana dijelaskan Teeuw (1979: 141), di dalam pengertian struktur terkandung tiga pengertian penting. Pertama, gagasan bahwa sastra merupakan satu seluruhan (wholeness) yaitu, bagian-bagian atau anasir sastra bersifat menyesuaikan diri dengan seperangkat kaidah instrinsik yang menentukan keseluruhan struktur maupun bagian-bagiannya. Kedua, gagasan transformasi (transformation), yaitu struktur tak statis, yang mampu melakukan prosedurprosedur transformasional dalam arti bahan-bahan baru diproses dengan prosedur dan melalui prosedur itu. Ketiga, gagasan mandiri (self regulation), yaitu tidak memerlukan hal-hal di luar dirinya untuk mempertahankan prosedur transformasinya. Bertungkus lumus dengan itu, eksistensi seniman dalam seni tradisi senantiasa mengundang perhatian para ilmuan dewasa ini. Proses kreatif dalam berkesenian yang dibalut dengan berbagai aktifitas sosial budaya dalam arti yang luas senantiasa menunggu untuk dibicarakan secara komprehensif. Kehadiran para seniman tradisional di tengah khalayak dalam setiap pertunjukan, telah memunculkan gagasan-gagasan baru dalam upaya masyarakat melakukan penataan terhadap berbagai aspek kehidupan sosial budaya.

Struktur pertunjukan, nilai budaya Seni Dendang, dan kehidupan sosial budaya seniman Seni Dendang di tengah masyarakat Bengkulu Selatan dilihat dalam variabel yang dikemukakan Setiadi dkk (2007: 39). Menurutnya, terdapat beberapa variabel yang berhubungan dengan perilaku hidup masyarakat terkait dengan persoalan sosial budaya dan lingkungan, yaitu : (1) physical environment, menunjuk pada perilaku dalam lingkungan natural seperti temperatur, curah hujan, iklim, wilayah, geografis, flora dan fauna; (2) cultural sosial environment, yang meliputi aspek-aspek sosial beserta proses sosialisasi seperti norma, adat istiadat dan nilai; (3) enviromental orientations and representations, mengacu pada persepsi dan kepercayaan kognitif yang berbeda-beda pada setiap masyarakat; (4) enviromental behavior and process, meliputi bagaimana masyarakat menggunakan lingkungan dalam berhubungan secara sosial; (5) out carries product, meliputi hasil tindakan manusia 
seperti membangun rumah, komunitas, kota beserta usaha-usaha manusia dalam memodifikasi lingkungan hidup mereka.

Tulisan ini dikemas ulang dari laporan penelitian yang dilakukan pada tahun 2012, berjudul "K ehidupan Sosial E konomi Seniman Seni Dendang di Kabupaten Bengkulu Selatan Provinsi B engkulu" . Penelitian dimaksud bersifat kualitatif serta data dan informasi dikumpulkan serta diolah dengan menggunakan teknik observasi, teknik wawancara, teknik rekam, studi kepustakaan, dan teknik analisis data. Dalam Endraswara (2003: 2007-2008), Danandjaja menjelaskan bawa penggunaan metode kualitatif dalam penelitian folklor disebabkan oleh kenyataan bahwa folklor mengandung unsur-unsur budaya yang diamanatkan pendukung budaya tersebut. Artinya, peneliti tidak hanya menitikberatkan perhatian pada unsur folk, namun juga unsur lore-nya. Kedua unsur ini saling terkait, sekaligus membentuk sebuah komunitas budaya yang unik. Data utama dalam penelitian kualitatif adalah kata-kata dan tindakan, selebihnya adalah data tambahan seperti dokumen dan lain-lain. Lebih lanjut, pada penelitian kualitatif, data bersumber dari manusia (human sources), berupa kata dan tindakan, sekaligus data di luar manusia (non human sources), berupa buku, dokumen dan foto.

Terutama untuk kepentingan analisis, data penelitian yang terkumpul dianalisis dengan menggunakan pendekatan analisis konten (content analysis). Krippendorf (dalam Burhan, 2001: 234-235) mengajukan beberapa klasifikasi dalam analisis konten, yaitu sebagai berikut :

1. Analisis pragmatis, dimana klasifikasi dilakukan terhadap tanda menurut sebabnya yang mungkin.

2. Analisis semantik, yang dilakukan untuk mengklasifikasikan tanda menurut maknanya. Analisis ini terdiri dari beberapa jenis, di antaranya analisis pertunjukan (designations), analisis penyifatan (attributions), analisis pernyataan (assertions).

3. Analisis sarana tanda (sign-vehicle), dilakukan untuk mengklasifikasi isi pesan melalui sifat psikofisik.

Analisis konten memiliki beberapa syarat, yaitu objektivitas, sistematis dan menyeluruh (general) (Muhadjir, 2000: 68). Oleh karena itu, materi penelitian, yaitu data dan informasi terkait struktur pertunjukan dan nilai budaya Seni Dendang, termasuk aspek-aspek sosial budaya seniman Seni Dendang, akan dianalisis menurut aturan dan prosedur yang telah dirancang secara objektif, sistematis dan menyeluruh. Tujuan akhirnya adalah, deskripsi aspek-aspek pertunjukan Seni Dendang serta penjelasan tentang nilai budaya Seni Dendang sebagai refleksi kearifan lokal (local wisdom) masyarakat Bengkulu Selatan.

Penggunaan analisis konten dalam penelitian ini ditekankan pada tiga aspek, yaitu aspek konteks (conteks), aspek proses (process) dan aspek emergence. Pada aspek konteks, situasi sosial budaya masyarakat Bengkulu Selatan dijelaskan dalam kerangka menghasilkan pemahaman kealamiahan (the nature) dan makna budaya (cultural meaning) dari objek yang diteliti, yaitu Seni Dendang. Kedua, pada aspek proses, yang ditekankan adalah bagaimana pesan-pesan nilai budaya masyarakat Bengkulu Selatan terkait dengan Seni Dendang diproduksi dalam konteks pertunjukan. Ketiga, pada aspek emergency akan dicermati upaya terbentuknya secara bertahap makna dari pesan komunikasi yang muncul pada saat observasi, wawancara, menyaksikan pertunjukan Seni Dendang, serta mengamati sosial budaya masyarakat Bengkulu Selatan, yaitu melalui pemahaman dan interpretasi dari peneliti. 


\section{PEMBAHASAN}

\section{Sekilas Kabupaten Bengkulu Selatan}

Masyarakat Indonesia dibangun oleh berbagai sukubangsa dengan kebudayaannya masing-masing. Menurut Jaspan (dalam Koentjaraningrat, 1986: 35), di Indonesia terdapat lebih kurang 656 sukubangsa. Setiap sukubangsa menempati suatu wilayah pemukiman yang dipandang sebagai pusat kebudayaan dan daerah penyebaran sukubangsa tersebut. Faktor inilah yang menyebabkan setiap wilayah di Indonesia dihuni dan terbagi atas wilayah sukubangsa tertentu (Koentjaraningrat, 1986 : 35). Masyarakat Bengkulu Selatan yang bersuku bangsa Seraway dewasa ini berada dalam wilayah administrasi Kabupaten Bengkulu Selatan Provinsi Bengkulu. Kabupaten Bengkulu Selatan berdiri berdasarkan Keputusan Gubernur Militer Daerah Militer Istimewa Sumatera Selatan pada tanggal 8 Maret 1949. Keputusan tersebut Nomor GB/27/1949, yaitu tentang pengangkatan Baksir sebagai Bupati Bengkulu Selatan (sebelumnya bernama Kabupaten Manna Kaur 1945 - 1948 dan Kabupaten Seluma Manna Kaur 1948 1949). Pada perkembangan selanjutnya, pendirian kabupaten ini dikuatkan dengan terbitnya Surat Keputusan Presiden RI tanggal 14 November 1956 dengan Undang-undang Nomor 4 Tahun 1956 (Tambahan Lembaran Negara 109) (BPS Kabupaten Bengkulu Selatan Tahun 2015).

Menurut Arsip Masatip, budayawan Bengkulu Selatan (wawancara tanggal 17 Maret 2013), Kabupaten Bengkulu Selatan juga dikenal dengan sebutan Seraway. Asal nama Seraway dikaitkan dengan dua pendapat. Pertama, istilah Seraway berasal dari kata sauai yang maksudnya cabang dua buah sungai, yaitu Sungai Musi dan Sungai Seluma yang dibatasi oleh Bukit Capang. Kedua, istilah seraway berasal dari kata seran yang artinya celako (celaka). Istilah ini dihubungkan dengan legenda anak raja dari hulu, karena menderita penyakit menular lalu dibuang (dihanyutkan) ke sungai dan terdampar. Anak raja inilah yang mendirikan kerajaan. Kerajaan Seraway terpisah dengan Kerajaan Bengkulu (Bangkahulu). Kerajaan ini ditemui antara daerah Sungai Jenggalu sampai ke muara Sungai Bengkenang. Kerajaan ini akhirnya terpecah-pecah menjadi kerajaan kecil yang disebut margo (marga). Marga dipimpin oleh seorang datuk dan membawahi beberapa desa/ dusun. Marga-marga di Kabupaten Bengkulu Selatan adalah, Pasar Manna, VII Pucukan, Anak Lubuk Sirih, Anak Dusun Tinggi, Kedurang, Ulu Manna Ilir, Ulu Manna Ulu, Anak Gumay dan Tanjung Raya. Seluruh marga bersatu atas dasar satu kesatuan, satu keturunan, dan satu rumpun bahasa.

Dalam sistem kekerabatan masyarakat Bengkulu Selatan digariskan bahwa tempat tinggal keluarga yang baru menikah akan ditentukan oleh perjanjian antara kedua belah pihak sebelum upacara akad nikah. Perjanjian tersebut pada dasarnya sama bagi suku Serawai dan suku Rejang. Biasanya keluarga dari kedua mempelai akan memberikan tiga kemungkinan status keluarga bagi pasangan yang baru menikah, yaitu asen beleket atau kulo reto, asen semendo atau kulo semendo masuak kampung, dan semendo rajo-rajo. Sejalan dengan ketiga bentuk perjanjian itu maka garis keturunan pasangan keluarga baru akan terdiri dari tiga macam pula, yaitu patrilinial (ikut garis keturunan ayah), matrilinial (ikut garis keturunan ibu) dan bilinial (bebas memilih, ikut garis ayah atau ikut garis ibu) (Erlis Harjoni, wawancara tanggal 13 Maret 2012). Kenyataan ini sesuai dengan penjelasan Fathilah (2007 : 2) tentang sistem kekerabatan, yaitu salah satu bagian dalam ilmu antropologi yang mengatur penggolongan orang-orang sekerabat dan melihatkan adanya berbagai tingkat hak dan kewajiban antara orang-orang sekerabat. 
Sebagaimana dijelaskan M. Baksim (budayawan Bekulu Selatan, wawancara tanggal 13 Maret 2012), secara umum pada keluarga batih, fungsi sosial, ekonomi, pendidikan, dan keagamaan menjadi tanggung jawab seluruh anggota keluarga. Seluruh pekerjaan di rumah tangga dikerjakan bersamasama secara gotong-royong, meskipun sebenarnya ada pembagian tugas di antara anggota keluarga. Sesuai dengan fungsinya, seorang ayah berfungsi sebagai pelindung keluarga dan melakukan pekerjaanpekerjaan yang berat. Ibu berfungsi sebagai penenang keluarga, dan ia melakukan pekerjaan-pekerjaan rumah tangga. Anak-anak berfungsi sebagai pengikat kasih sayang dan mereka bekerja membantu kedua orang tuanya dalam pekerjaan yang ringan-ringan. Bagi anak yang sudah dewasa, mereka akan membantu pekerjaan-pekerjaan yang sesuai dengan jenis kelamin mereka. Tanggung jawab orang tua terhadap anak hanya selama sang anak belum berumah tangga. Apabila anak tersebut sudah berumah tangga maka ia harus turun dari rumah dan mencari tempat kediaman sendiri. Kalau dia belum memiliki rumah sendiri maka dia dapat menumpang sementara di rumah orang tuanya atau di rumah mertua.

Setiap masyarakat (sukubangsa) memiliki seperangkat aturan yang bersifat mengatur pola kehidupannya sehari-hari atau lazim dikenal sebagai kebudayaan, yang dapat dikelompokkan dalam tiga wujud, yaitu pengetahuan budaya ide, gagasan), tingkah laku (aktifitas) dan budaya materi atau fisik (Koentjaraningrat, 1990 : 178). Pada masyarakat suku Serawai keluarga luas disebut ruguak. Rasa solidaritas dan kegotong-royongan antar sesama anggota klan sangat besar. Klan besar adalah himpunan dari klan-klan kecil. Di Bengkulu secara umum klan besar disebut marga. Kata marga berasal dari bahasa sangsekerta "varga" yang berarti kumpulan keluarga atau famili. Di kalangan Suku Rejang marga disebut juga dengan istilah petulai juei atau bang mego. Marga dipimpin oleh seorang kepala marga yang disebut pasirah, berasal dari kata sangsekerta "syrah" yang berarti kepala kaum. Dengan berlakunya Undang-Undang Nomor 5 tahun 1979 tentang Pemerintahan Desa, kedudukan pasirah hapus dan diganti dengan kepala desa dan kepala kelurahan. Sedangkan pimpinan adat diemban oleh seorang ketua adat.

\section{Sejarah Seni Dendang}

Diceritakan oleh Muksin, seniman Seni Dendang Bengkulu Selatan (wawancara tanggal 1 Maret 2012) terdapat dua versi cerita rakyat tentang sejarah Seni Dendang di Bengkulu Selatan. Cerita versi pertama, konon pada zaman kerajaan, tersebutlah dua kerajaan yang letaknya berdekatan. Kedua raja kerajaan tersebut, yaitu Raja Mangku Bumi dan Raja Mangku Jagat, masing-masingnya mempunyai seorang anak. Raja Mangku Bumi mempunyai seorang putra sedangkan Raja Mangku Jagad mempunyai seorang putri. Pada suatu hari kedua anak raja beserta teman-teman mereka bertemu pada satu tempat rekreasi. Mereka pun saling berkenalan serta kemudian mempunyai perasaan yang sama, yaitu perasaan suka. Kedua anak raja itu pun memadu cinta serta bersepakat untuk saling bercerita kepada orang tua masing-masing.

Sesampai di istana, anak raja Mangku Bumi mengabarkan kepada ayahandanya tentang pertemuannya dengan seorang gadis berparas cantik dan berbudi mulia. Menurutya, gadis tersebut sangat pantas untuk menjadi pendamping hidupnya kelak, terutama setelah jabatan sebagai raja dipindahkan ke pundaknya. Putra mahkota ini mengabarkan dengan penuh rasa hormat dan rendah hati. Sang raja memaklumi perasaan anaknya serta menanyakan siapa gerangan gadis berparas cantik tersebut, dimana alamatnya, serta tidakkah dia bagian dari orang-orang 
yang akan berkhianat kepada kerajaan. Sang putra mahkota pun menerangkan bahwa gadis yang dia maksud adalah seorang putri dari Kerajaan Mangku Jagat serta bertempat tinggal tidak jauh dari Kerajaan Mangku Bumi. Raja Mangku Bumi segera mengambil langkah bijaksana, yaitu datang ke kerajaan Mangku Jagad serta menerangkan niat putranya kepada Raja Mangku Jagat sahabatnya. Bertepatan dengan belangsungnya perundingan antara kedua orang berkuasa tersebut, sang putri Mangku Jagat keluar dari kamarnya serta diminta mengungkapkan kebenaran perasaannya kepada anak Raja Mangku Bumi. Menyaksikan itu, kedua penguasa tersebut bersepakat dengan maksud hati anak-anak mereka. Pada pertemuan itu juga dibuatlah waktu baik dan bulan baik guna menikahkan putra-putri mereka.

Masyarakat pun diundang untuk menghadiri acara perkawinan. Acara berlangsung demikian meriah. Pakaian kedua pengantin dibuat seindah mungkin dan susunan pernikahan juga diatur sebaik mungkin. Upacara besar-besaran tersebut sekaligus menjadi momen penting yang mencatat bersatunya dua kerajaan yang kemudian dipimpin oleh Putra Raja Mangku Bumi dengan permaisurinya putri Raja Magku Jagat. Seluruh peristiwa dan rangkaian kegiatan dalam acara perkawinan putra-putri raja tersebut kemudian dijadikan rujukan yang bersifat tetap untuk pelaksanaan upacara perkawinan di masa yang akan datang. Pelaksanaan upacara perkawinan sesudahnya secara sekaligus menjadi bentuk kegiatan memperingati tata urutan pelaksanaan perkawinan Anak Raja Mangku Bumi dan Raja Mangku Jagat. Dengan ketentuan tersebut, lahirlah kemudian istilah adat perkawinan, di dalamnya terdapat kemeriahan pesta yang sampai sekarang disebut dengan Seni Dendang serta dipakai secara umum di Daerah Bengkulu Selatan. Peraturan adat perkawinan tersebut kemudian juga disempurnakan dengan hukum pemerintahan dan hukum agama Islam di masa-masa selanjutnya.

Cerita versi kedua, sejarah Seni Dendang masyarakat Bengkulu Selatan dapat dirunut dari sebuah cerita yang berlatar belakang pada wejangan para nenek moyang Suku bangsa Seraway. Sebagaimana diulas kembali oleh Yarman (wawancara tanggal 21 Maret 2012), munculnya Seni Dendang dimaksudkan sebagai media pengungkapan perasaan dan kata hati dalam bentuk susunan kalimat-kalimat berirama serta akhirnya berbentuk sebuah pantun. Oleh masyarakat pemakainya dikemaslah kalimat-kalimat berirama tersebut menjadi satu bentuk kesenian yang dilengkapi dengan bermacam ragam alat yang keberadaannya sebagai penambah kemeriahan. Ragam alat yang dibuat itu berbentuk benda yang apabila digunakan dapat menimbulkan bunyi atau nada sesuai dengan yang dikehendaki. Singkatnya, perpaduan antara kalimat-kalimat berirama berbentuk pantun dengan ragam alat yang menghasilkan bunyi dan nada tersebutlah yang dianggap sebagai suatu kesenian, yaitu Seni Dendang.

Pelaksanaan penampilan Seni Dendang berfungsi sebagai hiburan bagi masyarakat, bernuansa gembira serta biasa tampil pada berbagai bentuk upacara, seperti pada upacara syukuran, yang terealisasi dalam tiga kegiatan adat, yaitu memotong rambut anak, sunah rasul, dan mendiami rumah baru. Seni Dendang juga biasa tampil pada upacara resepsi pernikahan. Pada upacara jenis ini pertunjukan Seni Dendang dapat dikategorikan menjadi dua macam, yaitu ;

1. Bedendang nunggu buah masak (berdendang menunggu buah masak). Kegiatan dendang ini dimulai dari mendendangkan dendang beledang serta berakhir pada dendang rampai. Tanda berhentinya dendang dilihat dari jenis tari yang ditampilkan 
dalam mengirinya dendang. Khusus pada bedendang nunggu buah masak, jenis tari yang ditampilkan hanya sebatas tari redok. Apabila penampil dan khalayak telah selesai menyantap juadah yang dihidangkan oleh tuan rumah maka berakhirlah penampilan bedendang nunggu buah masak.

2. Bedendang mutus tari (berdendang memutus tari).

Penampilan bedendang mutus tari juga dimulai dengan mendendangkan dendang beledang serta diakhiri oleh dendang rampai. Namun demikian, sebagai bukti telah memutus tari, maka penampilan dendang harus ditutup dengan menampilan tari rendai. Penampilan tari rendai biasanya pula diawali dengan menampilkan tari kain panjang, terus tari keredok, dan tari rendai (disebut melalukan) serta dituntaskan dengan penampilan tari orang mengempatkan. Apabila penampilan telah selesai maka dibuktikanlah dengan menatingkan jambar ke tengah lingkaran duduk para penampil. Orang dahulu menyebut jambar sebagai denda karena telah menampilkan tari kain panjang dan tari kerendai, karena kedua jenis tari ini adalah tari besar.

Menurut Khadam (wawancara tanggal 22 Maret 2012), urutan penampilan Seni Dendang (dendang dan tari) pada suatu upacara adat, baik peresmian perkawinan maupun upacara lainya yang menjadi adat istiadat sukubangsa Seraway (bedendang mutus tari) adalah sebagai berikut:

1. Penampilan dendang belidang dengan tari lemas.

2. Penampilan dendang lagu dua dengan tari sapu tangan.

3. Penampilan dendang kuyang madi dengan tari piring.

4. Penampilan dendang ketapang dengan tari mabuk, tari mainang, tari pulau pinang dan tari mengempatkan.

5. Penampilan dendang teraja dengan tari redok dan tari gendang.

6. Penampilan dendang mambang.

7. Penampilan dendang rampai dengan tari kai panjang.

8. Penampilan dendang mati dibunuh dengan tari rendai dan tari mengempatkan (berempat) sebagai penutup.

9. Penampilan talibun.

Menurut Sidarman, salah seorang seniman Seni Dendang (wawancara tanggal 20 Maret 2012), pertunjukan Seni Dendang berlangsung dalam beberapa urutan. Pertama, sebelum acara dimulai tua kerja akan menghadap kepala adat, yaitu dengan maksud memohon izin untuk membuka dan mempertunjukkan Seni Dendang. Kedua, kepala adat akan memberikan izin untuk menampilkan Seni Dendang dengan syarat segala persyaratan adat sudah dapat dipenuhi. Ketiga, sehabis pertunjukan dendang kuyang mandi yang diiringi tari piring, maka penampil akan beristirahat. Keempat, sebelum menampilkan dendang rampai, sepasang pengantin akan dihadirkan untuk duduk secara bersama dengan para penampil, biasanya berjalan sampai kegiatan istirahat. Apabila kegiatan istirahat berakhir, pengantin perempuan akan dibawa kembali masuk ke kamar, sementara pengantin laki-laki akan menunggu sampai penampilan ngantak rentak pengantin.

Kelima, selesai penampilan tari kain panjang, pengantin laki-laki akan ikut terlibat dalam penampilan ngantak rentak bersama empat orang penampil penari yang lain. Apabila penampilan selesai maka pengantin laki-laki akan dibawa masuk ke kamar. Keenam, setelah 
selesai tari megempatkan, tua kerja menghadap kepala adat guna menginformasikan bahwa pelaksanaan upacara telah selesai. Tua kerja kemudian menyerahkan jambar sebagai sangsi adat kepada kepala adat. Ketujuh, kepala adat menerima pengembalian pekerjaan tersebut beserta jambar yang diserahkan serta kemudian menyerahkan kembali jambar kepada tua kerja untuk dibagikan kepada semua peserta yang hadir. Delapan, setelah jambar tuntas dibagikan maka berakhirlah pertunjukan Seni Dendang.

\section{Struktur Pertunjukan Seni Dendang}

Beberapa aspek yang dinilai perlu untuk dideskripsikan terkait dengan struktur pertunjukan Seni Dendang sebagai berikut :

\section{Alat Pertunjukan}

Alat yang lazim digunakan dalam setiap pertunjukan Seni Dendang adalah, rebana, gendang panjang dua buah, biola, dua lembar kain panjang, empat lembar sapu tangan, dua buah piring, dua buah cincin, dua lembar selendang, satu buah payung, serunai, satu buah lengguai/sekapur sirih, pakaian seragam, dan pengeras suara.

\section{Waktu dan Suasana Pertunjukan}

Seni Dendang disebut juga sebagai seni khusus laki-laki. Pertunjukan kesenian ini berlangsung pada malam hari. Pertunjukan biasanya berlangsung sejak pukul $20.00 \mathrm{WIB}$ dan berakhir menjelang pukul $24.00 \mathrm{WIB}$. Biasanya pertunjukan berlangsung di lepau ahli rumah, atau di pentas yang dibangun khusus sebagai tempat berlangsungnya pertunjukan oleh ahli rumah. Anggota pendendang kebanyakan adalah orang tua-tua berjenis kelamin laki-laki dan sebagian kecil adalah pemuda yang pandai berdendang. Pelaksanaan dendang ditandai oleh lantunan nada dan lagu yang didendangkan serta bersifat saling berbalasan. Semuanya merupakan ironi, ada yang bersifat menyanjung dan ada pula yang bersifat merendahkan. Penampilan kemudian berjalan dalam suasana yang akrab, karena setiap penampil memiliki keleluasaan untuk saling menyanjung dan merendahkan. Oleh karena yang mengemuka adalah sebuah penampilan kesenian, maka upaya menyanjung dan merendahkan tersebut diterima sebagai sebuah atraksi yang bersifat menghibur, tidak hanya bagi khalayak yang hadir namun juga bagi para penampil itu sendiri.

Suasana penuh keakrababan sesungguhnya juga telah tampak sebelum penampilan Seni Dendang berlangsung. Bengulu Sanggau, ${ }^{1}$ sore hari menjelang pertunjukan berlangsung telah membuat undangan untuk para seniman Seni Dendang atau mereka yang pandai berdendang. Para seniman tersebut biasanya bertempat tinggal di dalam desa/kelurahan tempat hajatan berlangsung, atau bisa juga bertempat tinggal di luar desa/kelurahan itu. Biasanya, para pendendang tersebut terdiri dari mereka yang berasal dari satu grup Seni Dendang. Meskipun tidak tertutup kemungkinan berasal dari grup yang berbeda namun prioritas pertama adalah mereka yang berasal dari satu grup. Bentuk undangan tersebut adakalanya hanya disampaikan secara lisan serta tidak mesti langsung disampaikan kepada para pendendang, namun dapat diwakilkan kepada anggota

${ }^{1}$ Istilah sebutan yang digunakan oleh masyarakat Bengkulu Selatan terhadap Tua Kerja yang bertugas mengkoordirir pelaksanaan pertunjukan Seni Dendang. 
keluarga pendendang. Kenyataan tersebut mengimplikasikan bahwa telah terbinanya hubungan yang baik antar warga masyarakat, meskipun tidak berasal dari satu dusun, desa atau kelurahan. Hubungan baik itu pula yang mendasari berjalan meriahnya penampilan Seni Dendang.

Bersamaan dengan berjalannya undangan kepada para seniman Seni Dendang, Bujang Inang akan membawa lengguai sambil mendatangi semua sanak famili yang bedomisili dalam satu dusun dengan keluarga yang berpesta serta bermaksud menampilkan Seni Dendang. Biasanya, sanak famili tersebut juga memiliki kemampuan untuk berdendang dan menari, yaitu sebagai alternatif apabila sebagian besar pendendang yang diundang tidak memenuhi undangan, biasanya karena alasan cuaca atau ada keperluan lain yang sifatnya mendesak dan krusial. Diakui oleh Sukiran, seniman Seni Dendang (wawancara tanggal 17 Maret 2012), sejauh tidak ada halangan dan rintangan yang sifatnya mendesak, maka jarang bersua seorang seniman Seni Dendang tidak hadir memenuhi undangan satu keluarga yang bermaksud mengadakan penampilan guna memeriahkan pesta. Suasana hati dan perasaan yang senang serta bahagialah yang sebenarnya ada pada setiap pihak yang terlibat dalam pertunjukan Seni Dendang. Oleh karena itu, komunikasi dan interaksi berjalan hangat serta mewarnai berlangsungnya penampilan Seni Dendang, baik antara para penampil dengan tuan rumah dan khalayak, maupun antar penampil itu sendiri.

Senja harinya, sesudah makan malam yang juga dilangsungkan secara adat, sepasang pengantin akan kembali memakai pakaian adat secara lengkap. Mereka kemudian akan duduk bersanding dipengujung, yaitu istilah tempat untuk pertunjukan Seni Dendang. Kehadiran pengantin duduk bersanding dipengujung secara sekaligus menjadi lambang adat pada ' malam itu. Sementara pengantin berkemas, biasanya Pengulu Sanggau sudah sibuk menyambut undangan yang terdiri dari para pendendang, baik yang datang dari desa/kelurahan sediri maupun yang datang dari desa/kelurahan lainnya. Para undangan pun berangsur hadir dan kepala adat pun telah berada di lokasi pertunjukan. Pengulu Sanggau kemudia mengambil langguai dan mempersembahkannya kepada kepala adat. Penyerahan langguai tersebut menjadi prasyarat bahwa pertunjukan Seni Dendang akan segera dimulai. Oleh karena itu, pasangan pengantin akan dikeluarkan dari kamarnya untuk duduk bersanding duduk dipengujung (wawancara dengan Suharman, seniman Seni Dendang, tanggal 18 Maret 2012).

Suasana yang mengimplikasikan betapa dekatnya ikatan emosional antara para penampil Seni Dendang dengan anggota keluarga yang mengadakan pesta juga terlihat. Kenyataan tersebut ditunjukkan oleh terlibatnya pasangan pengantin dalam pertunjukan, yaitu sebagai perwakilan dari dua keluarga yang sudah terikat oleh hubungan bekulau. Permulaan pertunjukan Seni Dendang ditandai oleh terlibatnya pengantin laki-laki, yang lazim disebut dengan rentak pengantin nari. Selesai pengantin laki-laki menari, maka baru dipertunjukkan bermacam-macam dendang dan tari oleh para penampil, mengikuti urutan sebagaimana telah dijelaskan sebelumnya.

\section{Interaksi Penampil dan Khalayak}

Berlansungnya interaksi antara penampil dengan khalayak dalam pertunjukan Seni Dendang merupakan fenomena yang menarik untuk diperbincangkan. Oleh karena pertunjukan Seni Dendang diadakan dalam rangka memeriahkan berlansungnya prosesi perkawinan, maka khalayak yang hadir pun relatif terbatas, yaitu mereka yang secara adat dan budaya Bengkulu Selatan memiliki hubungan kekerabatan dengan keluarga yang sedang mengadakan hajatan. Lebih dari itu, kahalayak yang hadir 
adalah para jiran dan tetangga. Artinya masyarakat secara umum memiliki keterbatasan untuk hadir dalam setiap pertunjukan Seni Dendang. Terdapat semacam aturan yang melarang seorang warga untuk hadir dalam penampilan Seni Dendang apabila tidak diundang, meskipun aturan tersebut tidak tertulis. Kenyataan itu pula yang kemudian menjadi faktor penentu bagi berlangsung baiknya pertunjukan, termasuk persoalan interaksi yang terjadi antara para penampil dengan khalayak.

Meskipun penampilan berjalan dalam suasana yang akrab, dekat dan bersahabat, serta penuh kegembiraan, namun kesemuanya berada dalam koridor kepantasan menurut aturan adat perkawinan masyarakat Bengkulu Selatan. Oleh karena terbentuk dalam satu arena pertunjukan yang dibatasi oleh ketentuan adat, maka keleluasaan untuk berinteraksi antara penampil dan khalayak tidak terjalin secara leluasa sebagaimana terjadi ketika para warga menyaksikan penampilan orgen tunggal. Hubungan antara penampil dan khalayak dibatasi oleh ketentuan adat untuk saling berupaya menciptakan proses interaktif yang cair serta mengalir secara lepas. Menurut Yarman (wawancara tanggal 13 Maret 2012), dalam setiap pertunjukan yang dikuti, penampil tidaklah memiliki kebebasan yang bersifat mutlak dalam berinteraksi dengan khalayak, dan demikian pula sebaliknya. Di samping faktor aturan adat yang bersifat mengikat berlangsungnya pertunjukan tersebut, para penampil dan khalayak yang hadir di arena pertunjukan pun relatif telah berusia lanjut, sehingga bentuk-bentuk interaksi dan komunikasi yang berlangsung cair relatif sulit untuk terwujud.

\section{Teks Seni Dendang}

Teks seni dendang terdiri dari berbagai jenis teks lagu, yaitu sebagai berikut :

\section{Dendang Belidang}

Belidang adalah nama sejenis tumbuh-tumbuhan yang hidup di darat dan di rawa. Pada zaman dahulu, tumbuhan ini banyak tumbuh di areal persawahan warga. Belidang adalah jenis tumbuhan yang dapat tumbuh dibanyak tempat. Demikian pula teks lagu belidang, dapat dibawakan oleh orang yang memiliki vokal suara tinggi maupun orang yang vokal suaranya rendah serta dapat dibawakan oleh pendendang dengan vokal suara yang bagaimanapun. Oleh karena itu, setiap penampil Seni Dendang dapat dipastikan memiliki kemampuan untuk mendendangkan teks lagu dendang belidang.

Berikut teks Dendang Belidang :

Sayang mas mera sayang

$$
\text { Iiii...Tuan.... }
$$

Anak ikan dimakan ikan

Sayang mas mera sayang

Iiii... Tuan....

Anak ikan dimakan ikan

Selat (gaya mambang)

Selat (auh)

Dang dendang

Sayaup-sayup tegas

Bermakan ikan bermakan

Untung malang jadi begini

Ikan makan lumut batu 


\section{Dendang Ketapang}

Teks Dendang Ketapang sebagai berikut :

Sayang mas mera sayang

Sayang mas mera sayang

Gunung...

Selat

Sayang mas mera sayang

Iiii...Tuan...

Anak ikan dimakan ikan

Sayang....

Dang dendang

Anak ikan dimakan ikan

Gaya pantun

Dang dendang

Sayang (gaya tiga selasih)

Sayang(gaya tiga selasih)

Sayang(gaya tiga selasih)

Dang dendang

Selat

Selat

Ikan makan lumut batu

Untung malang jadi begini

Bermakan ikan bermakan

Selat

Sebalik teraja

Untung malang jadi begini

Sampai bunga karang layu

\section{Dendang Teraja}

Teks Dendang teraja sebagai berikut :

Iiii...Sayang iiii

Iiii...dang dendang iii

Iiii...Tuan aii

Anak ika dimakan ikan...

Gunung teraja 


\author{
Selat \\ Ikan dimakan ikan \\ Iiii...sayang aiii \\ Ikan bermakan \\ Sayang (anli) \\ Ikan makan lumut batu \\ Selat \\ Ikan dimakan ikan \\ Iiii...sayang aiii \\ Ikan bermakan \\ Sayang (anli) \\ Ikan makan lumut batu \\ Ngabiskan
}

\title{
4. Dendang Rampai
}

Teks Dendang Rampai sebagai berikut :

Auli sayang

Dendand dang dendang

Aiii ai anak ikan dimakan ikan

Aiii Sayang dang dendang

Aiii Sayang dang dendang

Bermakan ikan bermakan

Ikan makan lumut batu

Dang dendang sayang

Auli

Sayang sayup tegas

Bermakan ikan bermakan

Rampai-rampai

Sayang-sayang (sebalik teraja)

Sayang tegas

Rampai-rampai

Sayang-sayang

\section{Dendang Mambang}

Teks Dendang Mambang sebagai berikut :

Auli sayang

Anak ikan dimakan ikan

Mambang-mambang (kuntul)

Ikan bermakan aiii

Ayun dimambang

Ikan makan lumut batu

Tuan kasian

Sayang 
Bermakan ikan bermakan

Ayun dimambang

Ikan bermakan lumut batu

Tuan kasian

Sayang

Bermakan ikan bermakan

Ayun dimambang

Ikan bermakan lumut batu.

\title{
6. Dendang Senandung Gunung
}

Teks Dendang Senandung Gunung sebagai berikut :

\author{
Sayang-sayang \\ Aiii...tuaniii \\ Anak ika dimakan ikan \\ Senandung gunung \\ Sayang-sayan \\ Aiii...tuaniii \\ Anak ika dimakan ikan \\ Senandung gunung \\ Berakan ikan bermakan \\ Ikan dimakan lumut batu \\ Senandung gunung \\ Berakan ikan bermakan \\ Ikan dimakan lumut batu \\ Senandung gunung

\section{Lagu Duau} \\ Sayang dang dendang \\ Dimakan ikan sayang \\ Ikan makan batu dilumut batu \\ Sayang ikan makan batu dilumut batu \\ Kalau tidak tuan kasian \\ Tuan kasia sayagsampai bunga layu di karang layu \\ Sayang sampai bunga layu di karang layu
}

\section{Dendang Lagu Tari Piring}

Teks dendang yang mengiringi penampilan tari piring, biasa disebut dengan Dendang Lagu Tari Piring sebagai berikut :

Sayang aiii..

Anak ikan dimakan ikan $2 X$

Ikan makan duhai

Di lumut batu $2 X$ 


\author{
Aiii sayang-sayang \\ Dendang dang dendang \\ Sayang aiii...kalau tidak tua kasian $2 X$ \\ Aiiii sampai bunga aduhai \\ Aiii di karang layu $2 X$ \\ Aiii sayang-sayang \\ Dendang dang dendang.
}

\title{
8. Dendang Mati Dibunuh
}

Menurut Junaidi, salah seorang seniman Seni Dendang Bengkulu Selatan (wawancara tanggal 14 Maret 2012) nama dendang mati dibunuh berasal dari dua versi cerita. Pertama, nama ini mengacu pada pasangan pengantin. Setelah habisnya acara pada malam itu, mulai timbul ketukan di hati, baik pengantin laki-laki maupun pengantin perempuan, bahwa habislah cerita masa remajanya, karena keduanya telah saling menghabisi atau membunuh masa remaja masing-masing, sehingga berganti nama menjadi suami dan isteri. Kedua, nama dendang ini dirujuk pada kondisi bekas pacaran. Pada malam resepsi biasanya bekas pacar si gadis datang dan turut serta bersenandung dan berdendang dengan melampiaskan perasaan hatinya karena ditinggalkan pacarnya, rasa tersayat dan terbunuh ketikaitu.

Teks dendang mati dibunuh sebagai berikut :

Gunung baba sayang

Auli aiii...

Aiii dimakan ikan

Gunung baba sayang

Auli aiii...

Aiii dimakan ikan

Kalau tidak tuan kasian

Sayang dang dendang

Sampai bunga aiii di karang layu

Kalau tidak tuan kasian

Sayang dang dendang

Sampai bunga aiii di karang layu.

\section{Dendang Pulau Pinang}

Teks Dendang Pulau Pinang sebagai berikut :

Pulau pinang

Airnya deras aduhai sayang

Anyut batang

Anyut batang bujur melintang

Aduhai sayang

Anyut batang bujur melintang

Orang Palembang

Telampau keras aduhai sayang 


\author{
Bnayak dagang \\ Banyak dagang pulang berulang \\ Aduhai sayang \\ Banyak dagang pulang berulang \\ Mainang \\ Inang-inang inanglah sayang \\ Anak ikan dimakan ikan \\ Ikan makan aduhai sayangIkan makan di lumut batu \\ Aduhai sayang \\ Ika makan di lumut batu \\ Inang-inang inanglah sayang \\ Kalau tua tidak kasian \\ Sampai bunga \\ Aduhai sayang \\ Aampai bunga di karang layu \\ Aduhai sayang \\ Sampai bunga di karang layu
}

\title{
Tari dalam Pertunjukan
}

Terdapat beberapa jenis tari yang senantiasa ditampilkan dalam setiap pertunjukan Seni Dendang. Pertama, tari lemas. Lemas artiya lembut dan luntur. Jadi, tari lemas adalah perwujudan doa bersama dari seluruh komponen yang terlibat dalam pertunjukan, yaitu penampil, tuan rumah dan khalayak. Harapannya adalah, acara berjalan dengan mulus. Kedua, tari berempat. Tari jenis ini diperagakan oleh empat orang penari yang memiliki gerakan yang sama serta diiringi oleh nada rebana (gendang). Tari berempat tidak diiringi oleh nyanyian. Tari berempat merupakan tarian penutup pada pertunjukan Seni Dendang.

Ketiga, tari piring. Penampilan tari piring dilaksanakan oleh seorang penari, yaitu dengan bantuan alat peraga dua buah piring. Pada jari penari dipasangkan cincin yang keras, agar berbunyi ketika dipukulkan ke bagian belakang piring ketika gerakan tari dilakukan. Tari piring mempunyai dua gerakan. Pertama, penari akan menari dengan gerakan yang lemah gemulai serta tanpa bantuan alat tari berupa piring. Gerakan pukulan gendang yang mengiringi tari juga bersifat satai. Kedua, menari dengan gerakan lincah serta menggunakan alat peraga berupa piring dan cincin. Tari jenis kedua ini lazim diistilahkan dengan ketira. Gerakan menabuh gendang yang bersifat mengiringi penampilan tari piring adalah sebagai berikut :

Tak taum- tak tum tak tum tum $2 x$

Tak tum-tak tum tak tum tum $2 x$

Tak tum-tak tum tak tum tum

Tak tak tak tum tum tak tak tak tum tum

Tak tak tum- tak tak tak tak tum

Tak tak tum-tak tak tak tak tum 
Keempat, tari laguduau. Tari ini dilakukan oleh dua orang penari yang menggunakan alat bantu sapu tangan. Tari ini dilakukan dengan memerankan gerakan-gerakan tari yang bersifat berlawanan antara kedua orang penari. Ketentuan gerakan tari lagu duau terdiri dari dua gerakan. Pada gerakan pertama penari akan menari dengan gerakan lemah gemulai serta santai. Pada gerakan kedua yang biasa diistilahkan dengan ketira, penari akan melakukan gerakan-gerakan tari dengan gerakan selincah mungkin. Oleh karena itu, dendang yang mengiringi tari ini memiliki nada khusus, termasuk pukulan gendangnya juga khusus. Tari ini menggambarkan fenomena pergaulan antara bujang dan gadis, baik fenomena pertemuan maupun fenomena perpisahan, yang diperkaya dengan kiasan teks pantun bersahut serta digelar dengan tarian dengan memakai sapu tangan, yaitu sebagai tanda awal hubungan percintaan mereka.

Kelima, tari makinang/tari payung. Tari jenis ini mempunyai gerakan yang berlainan denga gerakan tari sapu tangan. Tari makinang diperagakan dengan bantuan beberapa alat tarian. Pertama, seorang penari memakai alat selendang dan seorang penari yang lain memakai payung. Kedua orang penari akan menari sambil mendendangkan pantun dengan suara yang indah serta bersifat saling berbalasan. Pada teks-teks yang didendangkan senantiasa tersebut kata-kata inang-inang sayang, yaitu berfungsi sebagai formula dendang.

Keenam, tari kuyang mandi. Kuyang adalah sebutan lokal masyarakat Bengkulu Selatan untuk menyebut sejenis burung. Burung Kuyang memiliki kesenangan mandi-mandi. Apabila Burung Kuyang mandi maka selalu mengeluarkan bunyi gemertak. Oleh karena itu, gerakan tari kuyang mandi meniru perilaku Burung Kuyang mandi serta menggunakan alat bantu berupa piring dan cincin. Ketujuh, tari kain panjang. Apabila bermaksud memperagakan tari kain panjang, maka ketentuan adat menggariskan bahwa pihak tuan rumah harus mengadakan atau menurunkan jambar sebanyak tiga buah. Tari ini dianggap tari besar. Gerakan tari ini secara umum merupakan gerakan bela diri, yang pada zaman nenek moyang merupakan bekal bagi para pejuang. Tari ini diperagakan oleh dua orang penari serta masing-masing mereka memegang kain panjang. Gerakan kain panjang diiringi oleh suara gendang serta nyanyian pendendang berisi kisah tentang keberadaan tiga orang raja pada zaman lampau, yaitu Raja Tiga Sila. Formula dendang menggunakan teks kumbang dinandi-dinandung.

Delapan, tari mabuk. Tari mabuk menggambarkan cara orang dahulu menangkap hewan yang akan disembelih untuk keperluan sebuah pesta, yaitu dengan cara menggiring hewan tangkapan sambil bertepuk tangan agar hewan tersebut masuk keberawan (tempat mengurung hewan buruan) yang telah disediakan. Setelah hewan tersebut masuk, maka orang banyak akan datang mengelilingi berawan sambil bertepuk tangan. Oleh karena tepukan dilakukan secara bersama dan serempak, hewan tersebut menjadi panik sehingga mudah untuk ditangkap dan disembelih. Barawan biasanya terbuat dari kawat, kayu ataupun tali, yang disekelilingnya dihiasi bermacam warna-warni dedaunan, sehingga mengelabui hewan yang ingin ditangkap. Tari mabuk juga terklasifikasi ke dalam tari besar. Tari ini diperagakan oleh dua orang penari, sama halnya dengan tari kain panjang. Namun demikian, penari tari mabuk tidak dilengkapi oleh alat peraga.

Sembilan, tari rendai. Tari rendai juga disebut dengan tari besar, sehingga sebelum diperagakan mesti pula menurunkan jambar seperti halnya pada tari kain panjang. Tari ini diperagakan oleh satu orang penari yang menari dengan gerakan sangat lincah dan berbobot, seolah-olah si penari sedang berkelahi dengan lawan yang tidak kelihatan. Rendai berarti panjang. Tari rendai adalah tari yang lebih panjang dan lebih banyak gerakannya apabila dibandingkan dengan jenis tari yang lain. Tari ini 
dimulai ketika pengantin dalam satu pesta perkawinan ngantak rentak pengantin dengan personil sebanyak lima orang atau lebih, diteruskan dengan tari kain panjang, langsung tari redok dan diteruskan dengan tari pencak silat.

Sepuluh, tari sapu tangan. Jenis tari ini memiliki gerakan dengan panduan nada pukulan gendang sebagai berikut :

\author{
Tak tum...tak tum \\ Tak tum...tak tum \\ Tak tak tum tak tum \\ Dan seterusnya sampai ketira \\ Tak tum tak tak tak tum \\ Tak tak tak tum \\ Tak tak tak tum \\ Dan seterusnya bertambah cepat.
}

Pertunjukan Seni Dendang telah berakhir. Para penampil pun kembali pulang ke rumah mereka masing-masing. Demikian pula para khalayak. Pada keesokan harinya diadakan acara pelepasan semua petugas yang terlibat pada pelaksanaan bimbang adat (pesta perkawinan). Pagi hari setelah semua petugas dikumpulkan, diadakan jamuan perpisahan kepada semua petugas yang telah membantu pelaksanaan bimbang, mulai dari hari pendudukan bimbang sampai pada bimbang selesai serta berjalan dengan lancar. Dalam upacara pelepasan ini tuan rumah juga menyampaikan ucapan terima kasih kepada semua orang yang terlibat, baik yang tugasnya berat maupun ringan. Sesudah acara jamuan makan bersama, mereka kembali bergotong-royong membersihkan semua kelengkapan pesta, seperti atar-atar dan penghujung (pentas). Semua dibongkar dan dirapikan hingga tuntas. Berakhirlah bimbang adat dan bimbang makan sepagi-rasa pakai uang.

\title{
Nilai Budaya Seni Dendang
}

Pembahasan terkait dengan nilai budaya Seni Dendang mengetengahkan hasil analisis berupa nilai budaya masyarakat Bengkulu Selatan yang direfleksikan oleh Seni Dendang, yaitu sebagai berikut.

\section{Nilai Seni}

Seni menawarkan keindahan serta keasyikan bagi penikmatya. Demikian pula kiranya yang mengemuka pada pertunjukan Seni Dendang. Nuansa nilai seni dalam pertunjukan Seni Dendang dapat diamati melalui teks-teks yag didendangkan, melalui gerakan-gerakan tari yang diperagakan, serta melalui berbagai atribut yang ada selama pertunjukan berlangsung. Nilai seni dalam teks tampak pada pilihan kata yang didendangkan, baik berbentuk pantun maupun berbentuk prosa liris. Nilai keindahan juga mengemuka pada setiap gerakan tari. Gerakan tari yang lembut dan lemah gemulai seperti terdapat pada gerakan tari lemas, maupun gerakan-gerakan yang terlihat cepat dan lincah seperti terdapat pada tari rendai, tari sapu tangan dan tari mabuk, pada prinsipnya menyuguhkan nilai seni yang mengagumkan. Oleh karena itu, secara naluriah khalayak yag hadir dalam pertunjukan Seni Dendang menjadi terpukau, meskipun kehadiran tersebut merupakan sesuatu yang telah berulang. 
Kelengkapan lain yang tampak dalam pertunjukan Seni Dendang, seperti alat bantu yang digunakan oleh para penari, seperti selendang, piring dan sapu tangan, ataupun pakaian yang digunakan oleh para penampil, kiranya juga menyajikan satu nuansa seni yang indah. Menurut Abadi, salah seorang seniman Seni Dendang (wawancara tanggal 14 Maret 2012) setiap kelengkapan tersebut memiliki nuansa seni yang apabila dipahami secara baik oleh khalayak maka akan terasa sebagai sebuah karya seni yang indah. Setiap kelengkapan pertunjukan tersebut ada dan digunakan sesuai dengan fungsi dan relevansinya degan nilai-nilai budaya masyarakat Bengkulu Selatan, sehingga keberadaannya tetap menjadi penting terutama sebagai media pelengkap bagi upaya pengajaran nilainilai seni berbasis kearifan budaya masyarakat.

\section{Nilai Pendidikan}

Berdasarkan keterangan Zarma (wawancara tanggal 14 Maret 2012), Seni Dendang dalam setiap pertunjukan yang diadakan terus berupaya mengajar dan mendidik khalayak dan masyarakat secara umum untuk terus mentauladani nilai-nilai kebaikan dalam menjalani setiap aspek kehidupan. Berbagai nilai kebaikan yang terus mengemuka dari setiap pertunjukan Seni Dendang adalah media pengajaran yang dinilai tetap relevan hingga masa sekarang. Pada pertunjukan yang diadakan dalam memeriahkan prosesi pernikahan warga misalnya, pendidikan tersebut tidak hanya ditujukan kepada khalayak dan masyarakat, namun juga kepada kedua mempelai serta keluarga yang tengah berbahagia. Pengajaran akan pentingnya kerelaan untuk berkorban, kesederhanaan dalam menjalani hidup, kelembutan dan kesahajaan dalam memperlakukan alam dan orang lain, serta ketegasan dan kecepatan dalam bertindak pada momeen-momem tertentu dalam hidup dan beraktifitas, merupakan contoh-contoh nilai kebaikan yang terus berupaya diwariskan ketika pertunjukan Seni Dendang berlansung.

Pertunjukan Seni Dendang berperan sebagai media pengajaran yang terus berupaya digalakkan oleh para seniman tradisional di Bengkulu Selatan. Pada konteks itu, eksistensi setiap grup Seni Dendang menjadi penting untuk terus dipertahankan. Keharusan tersebut terutama mengingat besarnya peran dari setiap pertunjukan terhadap keberlansungan proses pendidikan nilai budaya di tegah masyarakat. Oleh karena itu, apabila pertunjukan Seni Dendang semakin jarang diadakan, maka dapat dipastikan kalau upaya pewarisan nilai budaya masyarakat Bengkulu Selatan melalui media seni tradisi telah terhenti. Akibatnya masyarakat dan terutama para generasi muda akan kehilangan satu pilihan dalam usaha mengasah kepekaan seni, sekaligus watak dan karakter berbasis nilai budaya lokal.

\section{Nilai Pengorbanan}

Pengajaran arti pentingnya pengorbanan dalam menjalani hidup kiranya menjadi nilai budaya yang ingin diwariskan kepada masyarakat, khusunya kepada para generasi muda. Nilai tersebut mengemuka di antaranya melalui teks dendang mati dibunuh. Melalui teks dendang ini para pendendang mengajarkan bahwa kehidupan masa remaja yag penuh gelamor dan senda gurau mestilah berakhir, baik dalam kesukaan maupun dalam duka dan air mata. Setiap remaja tentunya menikmati kehidupan masa remaja mereka, khususnya dalam aspek pergaulan muda-mudi. Berbagai cita-cita dan rencana yang tertanam dalam pikiran setiap remaja tersebut dalam upaya menggapai masa depan mereka. Namun demikian, persoalan jodoh dan bagaimana nantinya hidup setelah menikah masih 
merupakan sebuah misteri yang sulit untuk ditebak dan dipastikan. Oleh karena itu, melalui teks dendang mati dibunuh diajarkan bahwa apabila harapan dan cita-cita ketika remaja tidak terwujud maka yang lebih harus dikedepankan adalah kerelaan untuk berkorban. Kenyataan bahwa sangat mungkin untuk melepaskan orang-orang yang dikasihi ketika remaja serta diharapkan akan menjadi pendamping hidup merupakan realitas yang mesti disikapi secara dewasa. Sebagaimana diisyaratkan oleh teks dendang mati dibunuh berikut :

\author{
Gunung baba sayang \\ Auli aiii... \\ Aiii dimakan ikan \\ Gunung baba sayang \\ Auli aiii... \\ Aiii dimakan ikan \\ Kalau tidak tuan kasian \\ Sayang dang dendang \\ Sampai bunga aiii di karang layu \\ Kalau tidak tuan kasian \\ Sayang dang dendang \\ Sampai bunga aiii di karang layu
}

Kerelaan untuk menerima takdir yang telah disuratkan oleh Yang Maha Kuasa serta kesungguhan untuk berkorban bagi kebaikan orang lain dalam kontek kehidupan bersama merupakan nilai budaya leluhur masyarakat Bengkulu selatan yang mengemuka pada teks dendang mati dibunuh. Seyogianya, ketika prinsip kerelaan untuk berkorban tersebut tetap dipraktikkan oleh masyarakat Bengkulu Selatan, maka kenyamaan dan keharmonisan hidup bermasyarakat akan terus terwujud, seharmonis gerakan setiap penari dalam pertunjukan Seni Dedang serta seindah suara pendendang ketika mendendangkan teks dendang mati dibunuh.

\title{
Nilai Agama dan Kepercayaan
}

Kehidupan beragama dan bekepercayaan merupakan aspek penting yang mesti dimilki oleh setiap kelompok masyarakat, termasuk masyarakat Bengkulu Selatan. Upaya penanaman nilai-nilai agama dan kepercayaan terhadap masyarakat tentunya telah ditempuh dengan memanfaatkan berbagai media yang relavan, termasuk pemanfaatan media seni pertunjukan semisal pertunjukan Seni Dendang. Tidak bisa tidak, pada konteks kehidupan masyarakat Bengkulu Selatan yang menghargai warisan leluhur di bidang agama dan kepercayaan, peran para penampil pertunjukan Seni Dendang menjadi urgen untuk dicermati. Keteguhan dalam memegang prinsip beragama dan ketaatan dalam mempraktikkan nilai-nilai kebaikan sebagaimana terus diwejangkan oleh para ulama di daerah ini merupakan agenda kemasyarakatan yang terus perlu diusung dan dipelihara.

Menurut Erlis Harjoni (wawancara tanggal 13 Maret 2012) pada aspek-aspek tertentu dalam pertujukan Seni Dendang, misalnya pada aspek teks dendang, pada aspek berpakaiannya para penampil pertunjukan yang sopan dan beradab, dan aspek-aspek lainnya, terkandung nilai-nilai luhur sebagaimana diajarkan oleh agama. Kepatuhan para penampil untuk tetap mengikuti pakem sebagaimana ditetapkan oleh para pendahulu seni tradisi ini, misalya dalam berpakaian, atau kehatihatian para khalayak pertunjukan dalam menjaga sikap dan perilaku selama hadir di arena pertunjukan, 
merupakan dua contoh penerapan nilai kesopanan dalam berpakaian dan kehati-hatian dalam bersikap dan berperilaku sebagaimanan diajarkan oleh agama. Lebih lanjut, kecenderungan untuk tetap berupaya menghormati tamu dan tuan rumah seperti terlihat pada prosesi perundingan yang berlangsung sebelum pertunjukan dimulai, ketika pertunjukan mengalami jeda istirahat ataupun setelah pertunjukan berakhir, yang terjadi antara ketua grup Seni Dendang dengan perwakilan tuan rumah, juga merupakan praktik perilaku yang mengamalkan nilai-nilai demokrasi sebagaimana diajarkan dalam kehidupan beragama.

\section{PENUTUP}

Kesimpulan dari tulisan ini, pertama, struktur pertunjukan dan sistem nilai budaya Seni Dendang merupakan dua aspek yang saling terkait serta bersifat saling menguatkan. Kedua, aspek tersebut akan mengemuka secara bersamaan dalam berlangsungnya pertunjukan Seni Dendang serta merefleksikan kearifan lokal (local wisdom) masyarakat Bengkulu Selatan. Aspek pertunjukan Seni Dendang, seperti alat pertunjukan, waktu dan suasana pertunjukan, interaksi antara penampil dengan khalayak, teks, dan tari, merefleksikan nilai budaya masyarakat Bengkulu Selatan. Beberapa nilai budaya yang berhasil dikemukakan adalah, nilai seni, nilai pendidikan, nilai pengorbanan, serta nilai agama dan kepercayaan.

Mencermati eksistensi Seni Dendang Bengkulu Selatan disarankan perlunya dukungan yang bersifat moril dan materi, terutama dari pemerintah daerah, agar proses kreatifitas seniman tradisional tetap berjalan. Bentuk dukungan tersebut mesti pula dipikirkan oleh banyak pihak yang terkait dengan eksistensi Seni Dendang, seperti pengurus, tokoh masyarakat, praktisi budaya di Bengkulu Selatan. Tanggung jawab bagi eksistensi seniman Seni Dendang Bengkulu Selatan mesti diemban secara sadar oleh berbagai pihak, sehingga keberadaannya tidak lekang oleh globalisasi di bidang seni budaya. Sadar budaya masyarakat Bengkulu Selatan diperlukan, agar Seni Dendang tidak lapuk oleh hujan ilmu pengetahuan dan teknologi yang pada satu sisi terus menggerogoti kehidupan kolektif masyarakat tradisional Bengkulu Selatan.

\section{DAFTAR PUSTAKA}

Teeuw, A 1979. Sastra dan Ilmu sastra : Pengantar Teori Sastra. Jakarta: Pustaka Jaya. Atmazaki. 2005. Ilmu Sastra : Teori dan Terapan. Padang : Citra Budaya Indonesia.

Bungin, Burhan (ed). 2001. Metodologi Penelitian Kualitatif : Aktualisasi Metodologis ke Arah Ragam Varian Kontemporer. Jakarta :PT RajaGrafindo Persada.

BPS Kabupaten Bengkulu Selatan. Kecamatan Kota Manna 2015.

Danandjaja, James, 1991. Folklore Indonesia Ilmu Gosip dan Lain-lain. Jakarta: Pustaka Utama Grafiti.

Endaswara, Suwardi. 2003. Metodologi Penelitian Budaya. Yogyakarta: Gadjah Mada University press. Kayam, Umar. 1981. Seni Tradisi Masyarakat. Jakarta : Sinar Harapan.

Fathillah, Nur. 2007. Sistem Kekerabatan Sub Etnis Palembang. Skripsi Sarjana. Palembang : Fakultas Adab IAIN Raden Fatah.

Koentjaraningrat. 1990. Beberapa Pokok Antropologi Sosial. Jakarta : Dian Rakyat 1986. Pengantar Ilmu Antropologi. Jakarta : Aksara Baru. 
Muhadjir, Noeng. 2000. Metodologi Penelitian Kualitatif. Yokyakarta: Rake Sarasin.

Masatip, Arsyid, 1998. Seni Dendang; Kesenian Daerah Suku Serawai di Bengkulu Selatan. (Tanpa Penerbit)

Setiadi, Elly M dkk. 2007. Ilmu Sosial dan Budaya Dasar. Jakarta : Kencana Prenada Media Group. 